\title{
ガス工業の趨勢と技術
}

\section{I. 沿革と現状}

わが国最初のガス事業は明治 5 年 (1872 年) 横济におこった。 これは英国で Murdoch が初めてガス照明の実験を行ってから 80 年後のことである。その後多少の盛衰はあったが，大体順調 な発展をとげ, 昭和 17 年 (1942 年) には需用家数 236 万, 年 間のガス消費量 13.3 億 $\mathrm{m}^{3}$ に達した。

しかし第 2 次世界大戦により爆撃, 石炭の不足, 需用家の衰 失, 装置と導管に対する修理遅延等によって終戦の年にはガスの 供給は昭和 17 年の $1 / 5$ に低落し, 最初は半分近いガスが漏洩し てしまうほどのみじめなことになって，ガスの供給も 1 日に数時 間というひどい状態が相当長い間続いたことは読者もまだ記憶さ

第 1 表 1955 年のガス統計

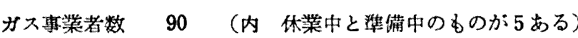
石宸ガス (コークス) 製造原料 (乾留):

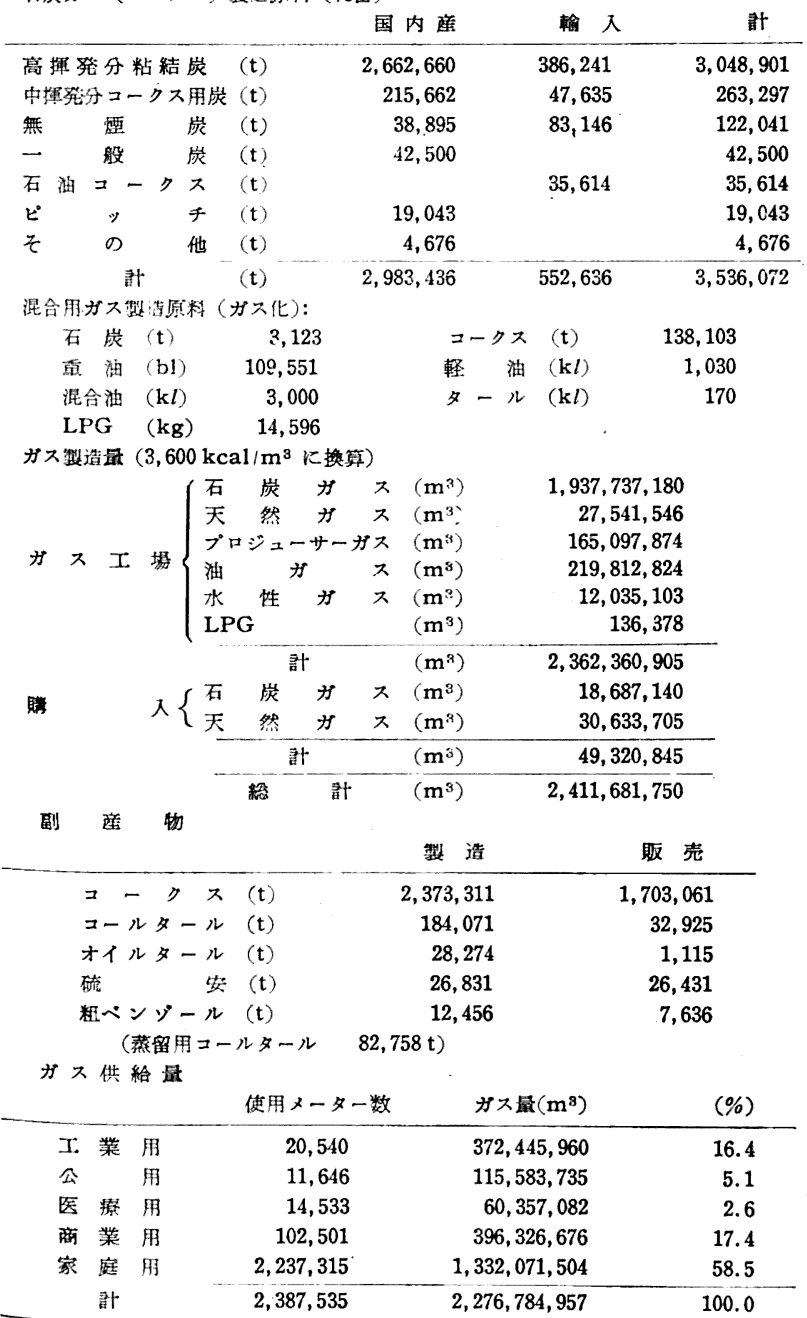

*日本瓦斯協会.
れていることであろう。その後ガス事業者の不断の努力によって 1946 年以降は急激に回復し, ガスの供給量は 1951 年に早くも戦 時中の最高においつき, 1956 年には 26 億 $\mathrm{m}^{3}$ となり, 需用家 数も 270 万となった。すなわち需用家数では戦時中のピークを少 しく超え，ガス量は 2 倍になった。な扮勘定外ガス（主として漏 洩）の量も3\% 台に減少した。

最近の統計（1955 年）にしたがえば，わが国のガス工業は第 1 表のようである。

この統計によれば都市ガスの $80 \%$ までは石炭の乾留による石 炭ガスであって, 天然ガス, 油ガス, 增熱水性ガス, プロジュー サーガス等の量は合計して $20 \%$ である。

ガスの需要が大都市に集中することは自然の理であるが，東 京, 横浜, 名古屋, 京都, 大阪, 神戸のいわゆる六大都市だけで 全ガス量の約 $83 \%$ を消費している。

ガス工場のガス製造設備は工場によりいちようでなく, 中小都 市のあのは一般に水平レトルト（有底式または貫通式）が主要な あのでそれによって生じる石炭ガスを空気または石炭あるいは コークスを原料として製造したプロジューサーガスをもって熱量 を調節するのが常法である。しかし東京, 名古屋, 大阪, 神戸等 の大工場にあっては、コークス炉が主要なガス製造装置となり， これにコークスを原料とするプロジューサーガスの他に需要の増 加にしたがって增熟水性ガス，油ガス等をつくって混入するもの が多い。

天然ガスはその生産地が限定されているため，その入手に恵ま れている工場のみが用いるもので，主として裏日本（秋田県から 石川県まで)，千葉県，長野県の一部で利用されているにすぎな い。かつ使用量す熱量基で全ガス量の堡かに $2.4 \%$ である。

今日本のガス工業の規模を世界の主要国とくらべると第 2 表の ようである。

第 2 表 世界各国のガス工業の大貌

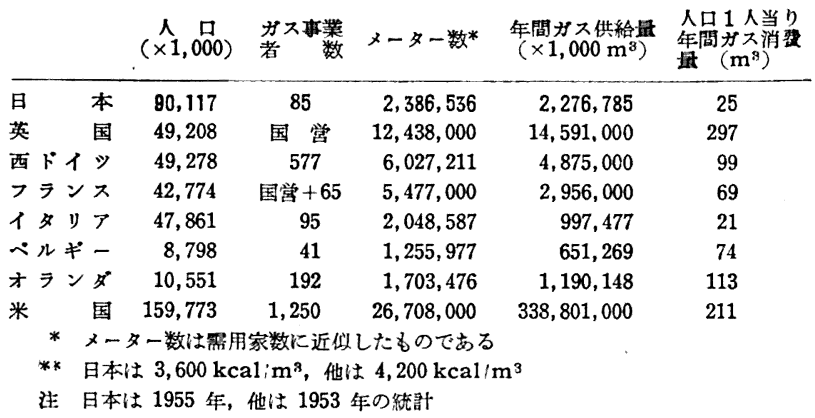

\section{II. 都市ガスの製造}

\section{1. 石炭の乾留}

前述のごとく，わが国の都市ガスはその $80 \%$ までが石炭の乾 留による石炭ガスであるから，ガス工業は一面ヌークス工業であ あって，鋳物用コークス，カーパイド用コークス，水性ガス発生 
用コークスまたは溶鈗炬用コークス等品位の高いコークスを製 造，供給することもまたその使命である。それであるから国内産 の葫留用炭だけではその目的を達しえず，配合用として鋳物用二 一クス製造のため昔からホンゲー無壉炭を輸入しており，一般硬 コークス製造のために戦前支那から輸入されていた中揮発分コー クス用炭に代って戦後は主として米国から優良な中，または低揮 発分コークス用炭を輸入しなければならなくなった。そればかり でなく，過去数年間はガス製造用として高揮発分の低灰分の粘結 炭も相当量米国から輸入されている(第 3 表参照)。

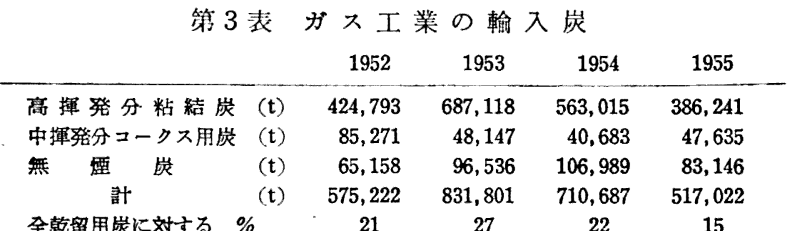

わが国のガス工場の石炭乾留量を他国のものと比較すると次の ようである。

第 4 表 各国のガス工場の石炭乾留量 (単位 : $t$ )

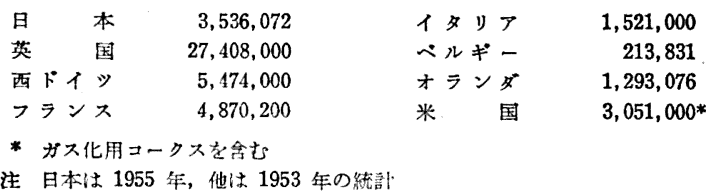

乾留は永い歴史を有するもので，ガス工業のほかに製鉄工業， 化学工業等でも行われている。ただガス工業では他産業と同様に コークス炉を用いるほか, 水平レトルトや小型室式炉等ガス工場 独特のものを用いるのはその一工場の規模が比較的小さく，かつ ガスを主産物とするためである。

乾留の場合, その目的がガス製造以外にコークスの品位向上を も目標とする時には原料炭の配合に注意しなければならぬ。事実 わが国には適当なコークス用炭の産出がほとんど皆無であるた め, 配合の技術と石炭の変性についての技術はおそらく世界で最 あ進んでいると思われる。またガスの得熱增加とコークスの品質 改善を兼ねて装入炭に少量の石油製品の添加は興味あることであ るが，末だ一般的には行なわれていない。

（a）コークス炬 コークス炉の設計, 築造, 運転はほとんど 標準化されており, 個々の機械的設備, オートメーションの方法 等以外には今後著しい改良が望めないほど完成されたものと言っ てょい。

わが国では東京, 名古屋, 大阪, 神戸, 谷等のガス工場に設置 され，その数 736 㧟 (1955 年) である。

（b）水平レトルト ガス工場独特のもので有底式（一畦の装 炭量 $=150 \sim 200 \mathrm{~kg}$ ） と貫通式（一坩の装炭量 $=400 \sim 600 \mathrm{~kg}$ ）の 2 種類がある。その数前者は 2,861 , 後者は 2,253 で非常に多い が，乾留技術から見れば原始的であることをま收がれない。

ただ最近流 予氏の創案による T.S. 式高圧装炭方法が完成 し, $60 \mathrm{~kg} / \mathrm{cm}^{2}$ の圧力で装炭をブリヶット状として装入してコー クスの性状を改善し兄たことは特筆に值する。ちなみにこの方法 は四国のガス工場で実施されている。

（c）小型室式炉 貫通式水平レトルトに代るべきもので，戦 後その数が急增し, 1955 年には 146 炉となり, その構造も漸次 改善されつつあることは閔ぶべきことである。
この式の炬はわが国では益子勉二氏が若林金五郎氏と協力して 1936 年に宇都宮のガス工場に設置したのを䋨矢とする。本式の 一师の装炭量は 1.5 3t で乾留時間は 12２4 hr の間にある。 装排炭が全部機械化されていることはコークス姖とほぼ同様であ るが，炉の加熱が内設式プロジューサーによることが異っている。

（d）連繶式直立炉 英国のガス工場では今なお多く用いられ ているが，わが国では前には用いられたことがあったが，これに 適する原料炭の入手が容易でないため現在では姿を消した。今後 この式のものの再現は望みがない。

(e) 断綂式直立炉 これに反し断続式直立炉は興味がある。 本式のものは水平レトルトと同一の原料炭が用いられ，コークス 帄のごとく押出機を必要としない。その上，スチーミングを行っ てガスの増量をうることは連続式と同様である。

久しい昔, 名古屋と京都のガス工場にこの式のものがあって, 成績がよくなかったということを聞いているが，最近のものは構 造を改良して昔の欠点（主としてコークスの品質不均一）は除か れたものと思 5。1 日数万 $\mathrm{m}^{3}$ のガスを製造する工場には敷地と 人件費の節約のためにも適当した昈であると信じる。るっとも地 震の多い土地にはその構造上す寸められない。

（f） 流動式乾留炉 これは全く異ったプリンシプル，すなわ ち動態 (Fluidization) で石炭粉を乾留するるので，すべての従 来の乾留炉が粘結炭を必要としたのに反し，これは非または弱粘 結性炭を要求し，しかも粉末状でなければなら妨。したがって乾 留残留物は粉状のコークスであるが，内外併熱式を用いれば十分 都市ガスとして満足されるガスがえられる見込みがある。また装 置の大きさに対し能力が著しく大となることもこの式の特長であ る。しかし未だ工業的に操業されるまでには至って扣らず，わが 国では資源技術試験所の照井第一部長の下で試験，研究が続けら れている。

\section{2. 石油重油または軽油のガス化}

最近のガスの需要の特長として一般に夏冬の需要の羑が著しく 大きくなったことを挙げなければならぬ。そのために冬期のピー ク対策として比較的建設費のやすい，かつ高熱量のガスを発生す る装置が望まれて来た。1952 年の末, 東京瓦斯 K.K. が初めて 本格的な油ガス製造装置の運転を開始したことはわが国のガス工 業のエポックを画したものである。

（a）油ガスブラント 現在，東京や大阪のガス工場に設置さ れたものはいずれる high B.T.U. 式のもので, 水性ガスプラ ントと同様 blow-run 作業による。しかし，わが国のよ5に石炭 ガス基の都市ガスを供給する所では，現在のガス器具で満足に然 烧するためにはかかる high B.T.U. 油ガスの混入率は自ら制限 がある。

それであるから，わが国では触媒を利用してクラックして $\mathrm{H}_{2}$ の量を增やす ONIA-GEGI または SEGAS 式のよ5に一挙にし て従来の石炭ガス基のガスに酷似した性質を有する油ガスの製造 方法が最も適当しているのであるが，未だにその実現をみないの は不思議である。

（b）小型油ガス化装置上記のものはいずれも相当大規模の ものであるが，中小ガス工場で籣単な油ガス装置の出現が望まれ ている。もし，ガス化剤としてスチームの他に酸素が使用できれ ばいっそう興味がある。

（c） 水平レトルトを応用する油ガス化 1952 年末の石炭ス 
トライキ当時から在来の水平レトルトを応用して応急的な, 姑息 な重油ガス化を試みた小工場が数カ所あったが，効率が悪いこと と, 発生するタールの処置に困って長続きはしなかったようであ る。

\section{LPG}

最近ビン詰のいわゆるプロパンガスの進出は目覚ましいが, ガ ス工場でも冬期ピーク時の対策として LPG（主としてブタンとブ チレン) をガス化して混入することが広く行われ出した。しか し，これも high B.T.U. 油ガスと同じく，無制限に混入するこ とができず, 最近, 大阪瓦斯 K. K. 器具研究所でガス器具別に その混合可容率を定めたことは有益な研究であった。

わが国では1955年にはガス工場で LPG は僅か $15 \mathrm{t}$ しか使用 されなかったが, 1956 年には石油精彆工場より 4 万 $\mathrm{t}$, 天然ガス から 4 千 $\mathrm{t}$ 合計 4.4 万 $\mathrm{t}$ の $\mathrm{LPG}$ が製造されると見込まれてい るから，ガス工場での使用も今後急增するすのと思える。

ヨーロッパ諸国の LPG の一般的消費（ガス工場用も含む）は 第 5 表に示したようである。

第 5 表 $\exists$ 哦各国に拈ける LPG の消費 (1954 年)

\begin{tabular}{|c|c|c|c|}
\hline 菻 & 55,000 & イタリア & 290,000 \\
\hline 西 ドイッ & 165,000 & ベルギー & 83,000 \\
\hline ス & 350,000 & オランダ & 9,150 \\
\hline
\end{tabular}

とくに, フランス, イタリアではその利用が著しく, 前者では 都市ガス需用家数とほとんど同様（約 500 万）のビン詰 LPG の 利用家があり, 後者でも約 500 万の利用家があり, 都市ガス需用 家数の 2 倍以上となっている。

わが国でも LPG についてはガス事業者がもっと関心を持ち, これをライバルと考えないで自己の事業の中に抱き入れるくらい の考えを持つことが望ましい。今後益々生産が増加し, 価格も低 下寸るであろうこの貴重な資源を上手に使うことが必要である。 それにはガス工場用としてはその儘では利用率が制限されるの で,ぞうしてもリフォーミングを行らことが必要となってくる。 リフォームさえすればその混合率は無制限となるのである。

\section{4. 水 性 ガ ス}

戦前わが国の大ガス工場では石炭ガスに水性ガス（ブリューま たは增熱）を混じて供給するものが多かったが，水性ガス製造原 料のコークスが比較的高価なため, いつしかその製造を止めてし まった。それが 1954 年末以来再び多くのガス工場で取り上げら れたのは興味あることである。それは（i ）当時コークスの有利 な販売がむずかしかったこと。（ii）增熱水性ガスプラントの構 造, 操作が著しく進歩し，作業費が低下したこと。（iii）増熱油 として従来は一定のガス油（軽油の一種）にかぎられていたもの が戦後英国で重油を用いることに成功したこと等の理由による。

1954 年末から 1956 年中に英国の PGC 式と Humphreys \& Glasgow 式の最新式の增熱水性ガスプラントが名古屋, 大阪, 広島, 沼津, 福岡, 京都等のガス工場に計 18 基建設され, その 稼動能力合計 129 万 $\mathrm{m}^{3} / \mathrm{d}$ に及ぶ盛況を示した。

外国（たとえばスコットランドや濛州）では水性ガス製造の原 料として特殊な石炭を利用することにより増熱油の節約に成功し た例もあるが，わが国の石炭事情ではほとんど望みがないものと 思5。

\section{5. プロジューサーガス}

コークスを原料とするプロジューサーガスは従来大工場でコー
クス炉の采坩然料とすると同時に石炭ガスの希釈用に用いられて いたし，今後もまたそのと拉りに続いて行くことには疑いない。

一方，石炭を原料とするプロジューサーは戦前にはガス工場で は見られなかったものである。それが戦後各所の小ガス工場で独 自の設計による小型の石炭プロジューサーが現出したのは面白 い。しかし初めはいずれもガスの精彆（タールの除去）に苦しん だが，現在では大体その困難は克服しえたようである。これらの プロジューサーでは燃料層を比較的高くして一部低温乾留を行わ せ, $1,600 \sim 1,700 \mathrm{kcal} / \mathrm{m}^{3}$ 程度の比較的高カロリーのガスをえ ている。中には他産業の酸素を㲘入して空気に混じて $2,0 J 0$ $\mathrm{kcal} / \mathrm{m}^{3}$ 程度のガスをえているものもある。

\section{6. 天 然 ガ ス}

わが国の 1955 年の天然ガス生産量は石油を伴な5もの (wet) $29,454,030 \mathrm{~m}^{3}$, 伴なおないもの (dry) $125,770,000 \mathrm{~m}^{3}$, 計 $155,224,000 \mathrm{~m}^{3}$ でその産地は 1 道, 1 都, 10 県にわたっている が，その内都市ガスとして利用されたものは $14.3 \%$ (主として 新潟地区）にすぎない。これを外国の例とくらべると次のように なる。

第 6 表 天然ガスの生産と都市ガスとしての利用

$\left(\times 1,000 \mathrm{~m}^{3}\right)$

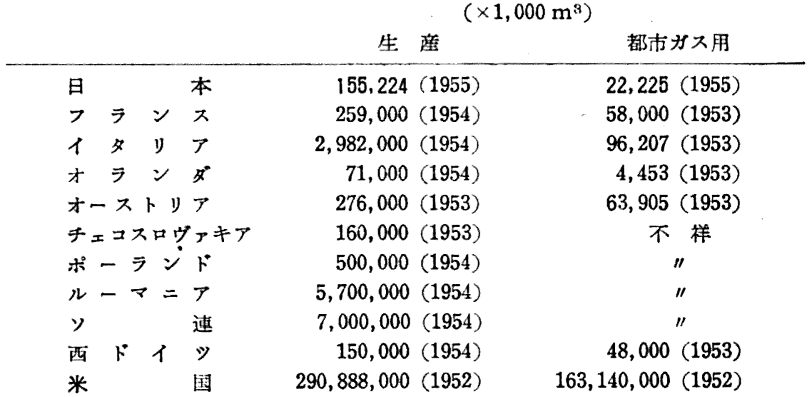

しかし各国の天然ガスの産量および利用度は最近急激に增加し ているから第 6 表の数値はあまり参考となら妨知れない。

天然ガスの都市ガスとしての利用は遠距離輸送管の設備のない わが国では地域的に制限されている。な拈わが国ではその埋蔵量 に十分に信頼しうるものが欠けているかに見えるのは遺憾であ る。しかし，この地下に眠っている貴重な資源は経済的である範 因においてはできるだけ都市ガスとし, 燃料とし, また化学合成 原料として利用することは望ましいことである。

\section{7. 石炭のガス化}

普通石炭のガス化という時は従来からある石炭プロジューサー のことは含まないのが常である。

約 20 年ほど前, わが国でいわゆる“石炭の完全ガス化”と称 せられて Tully, Strache, Kreisa, VIAG らの double-gas 法 が一時流行したことがあった。最近, 特に戦後種々新らしいテク ニクが石炭のガス化に取り入れられ動態 (Fluidization), 流態 (Entrainment), 加圧状態でガス化することが研究され, 原料の 選択範用が著しく拡大され，昔は思いも及ばなかった低品位炭を 処理することができるようになった。これらの方法の中にはすで に工業化されたものもあり，たと竞ば Lurgi の加圧ガス化， Koppers-Totzek の微粉炭ガス化のごときである。

今わが国のガス工場で建設されたものに VIAG 式から発展し た GI 式ガス化装置がある。これは東京瓦斯 K.K. 豊洲工場に 建てられたもので, 径 $3.6 \mathrm{~m}$ の『 5 基で 1 基の能力は次のよ5 に予想されている。 
增 熱なし

コークスを原料とする場合

石炭を原料とする場合
$150,000 \mathrm{~m}^{3} / \mathrm{d}\left(@, 2,700 \mathrm{kcal} / \mathrm{m}^{3}\right)$

$120,000 \mathrm{~m}^{3} / \mathrm{d}\left(@ 3,200 \mathrm{kcal} / \mathrm{m}^{3}\right)$
重油で增熱した場合 $150,000 \mathrm{~m}^{3}$ (@) 4, $\left.200 \mathrm{kcal} / \mathrm{m}^{3}\right)$ $120,000 \mathrm{~m}^{3}\left((a), 4,200 \mathrm{kcal} / \mathrm{m}^{3}\right)$
本プラントは最近コークスを原料として操業開始されたが, こ れは同式のものの中でも世界最大のものであり, かつ日本産の石 炭でよく所期の能力を出しうるかどうか非常な興味をもってその 作業成績が待たれている。

都市ガスの面よりすれば, 比較的低品位の石炭から一挙に石炭 ガスに酷似した $3,800 \sim 4,000 \mathrm{kcal} / \mathrm{m}^{3}$ のガスを発生する Lurgi の高圧ガス化法が最も與味の深いものであって, ドイッの Dorsten の Steinkohlengas A.G. (1955 年末操業開始, 5 億 $\mathrm{m}^{3} /$ year), 嫁州の Morwell の The Gas and Fuel Corporation of Victoria (1956 年末操業開始, 1.7 億 $\mathrm{m}^{3} /$ year) の例はわが 国においても同式採用の可能性があることを示している。この場 合, 低品位炭利用の建前からガス発生装置を炭坑の近くに設ける とすると，ガス消費地までのガス輸送管は欠くことのできないも ので, Lurgi 式ならばガスは初めから $20 \mathrm{~atm}$ 以上の圧力を持っ ているから遠距離輸送にはきわめて都合がよい。

都市ガス工業では高熱量ガス以外のものは全く興味がないとい らわけではなく、 ニークス炉の采圤, 高熱量ガスの希釈等に現在 のプロジューサーガス以上に廉価なガスがえられるならば大いに 歓迎するところであるが，現在まだそれほど蛛力のある方法はな いようである。

\section{8. 坑内 ガ}

最近, 北海道の石狩炭田や北九州の炭田でメタン濃度の高い坑 内ガスの抽出が行われ出した。一部ボイラー用然料またはアンモ ニア合成用ガスとして利用されている。このガスはメタン 55〜 $65 \%$ (時には $70 \%$ 以上) を含み, 都市ガスとして理想的なるの ではないとしても增熱用として価值の高いもので, 炭坑の抽出個 所とガス消費地の間にガス輸送管さえあればいつでも利用できる． ものである。

\section{9. 地下ガス化}

わが国では未だ実施されていないが、ヨーロッパの各地である 程度行われている地下ガス化によるガスは, 都市ガスとしては縁 遠いものである。

10. メタン合成 (Methanization)

触媒の作用で $\mathrm{CO}+3 \mathrm{H}_{2} \rightarrow \mathrm{CH}_{4}+\mathrm{H}_{2} \mathrm{O}$ の反応を起すことはす でに公知のことであるが，これを工業的に経済的に行らことは未 だ成功していないようである。この転換は熱経済的には不利なも のであるが，都市ガスとしては低熱量のガスが多いよりも，少な くても高熱量のガスの欲しい場合が多く，もしプリュー水性ガス から安価に，かつ簡単にメタンが合成されることとなればその利 用価值は甚だ大であるといいうる。

\section{1. 液態メタン}

ヨーロッパにおいては他国から天然ガス中のメタンを液化した ものを多量に輸入することもすでに話題に上っている。これは現 在莫大な量の天然ガスが中東, ヴェネッ゙ェラで空しく空中に㶳て られているし，将来サハラに执いても同様な浪費が起るであろ5 ことから考岳されたことである。前二者において空費されてい る天然ガスの量は年間石炭ガスに換算して 600 億 $\mathrm{m}^{3}$ に相当す るといわれる。

\section{2. 他産業のガスの利用}

わが国ではガス事業者が他産業（たとえば製鉄工業や化学工 業で生産するコークス渵ガスを購入して都市ガスとして供給す） ることはその例も少なく，またその量もきわめて少ない。1955 年の統計にしたがえば全ガス量の僅か $0.03 \%$ にすぎない。しか るにヨーロッパに怙いてはガス網が発達していて都市ガスの大部 分を他産業のコークス炉ガスに仰いでいるものもある。第 7 表は その間の事情をよく物語っている。

第 7 表 ヨーロッパ各国の都市ガス供給網中に入ったコークス 炉ガスの量とその比率 (1954 年)

\begin{tabular}{|c|c|c|c|c|c|c|c|c|}
\hline & & \multirow{2}{*}{\multicolumn{2}{|c|}{$\begin{array}{l}\text { ガス事業者の } \\
\text { 生产じス }\end{array}$}} & \multirow[b]{2}{*}{$\begin{array}{l}\text { ガス網中に } \\
\text { 人つたコー } \\
\text { クス炉ガス }\end{array}$} & \multicolumn{3}{|c|}{ (単位 : 100 万 $\mathrm{m}^{3}$ ) } \\
\hline & & & & & & $\begin{array}{l}\text { その他 } \\
\text { のガス }\end{array}$ & 計 & $\begin{array}{l}\text { ガス絧中に入つ } \\
\text { たコークス炉开 } \\
\text { スの比率 }(\%)\end{array}$ \\
\hline ヘ & ル & ギ & - & 54 & 801 & 107 & 962 & 83 \\
\hline 7 & ₹ & ン & ス & 2,231 & 608 & 11 & 2,850 & 21 \\
\hline 英 & & & 国 & 14,550 & 2,121 & - & 16,671 & 13 \\
\hline 西 & $r^{*}$ & 1 & シ & 2,563 & 5,972 & - & 8,535 & 70 \\
\hline
\end{tabular}

ガス事業は元来公益事業であるため, ガスの供給を他産業に頼 ることは一応危険であるとみることができるが, 将来ガスの需要 が急増し，ガス工場の生産がそれに追いつか奴場合には，わが国 でも考えなければならぬ問題で, 事実その方向に向っているとい うことができる。

\section{III. ガスの 精 製}

石炭を原料とする時乾留ですガス化でも粗ガス中には水, アン モニア, 硫化水素, 有機イオウ化合物, 酸化窒素等の不純物を含 んでいる。現在ガス工場で行われているガス精製の方法は一応満 足すべき状態にあるが，一工場の規模が著しく大きくなる場合， ガス精撆の装置も膨大なものとなる。すなわち現在の方法では装 圆の大きさ, ガス管の口径, バルブの製作技術等から 100 万 $\mathrm{m}^{3} / \mathrm{d}$ 程度の精製装置が最大限度と考えられているが，もし $10 \mathrm{~kg} / \mathrm{cm}^{3}$ 程度の高圧下精製法を採用すると 200 250 万 $\mathrm{m}^{3} / \mathrm{d}$ 程度までは 一系列の装置で処理することが可能となる。かつ高圧下では精製 度を著しく向上させうる利点もある。

東京瓦斯 K.K. の計算によれば, ガス $1,000 \mathrm{~m}^{3}$ 当り精製費 用は次のようである。

常圧精䌘法（圧送費を含む）約 702

高压精製法（加圧費を含む）約 $¥ 630$

ちなみに同社豊洲工場の高圧ガス精製 (200 万 $\left.\mathrm{m}^{3} / \mathrm{d}\right)$ 一系統 のフローシートは次のようである。

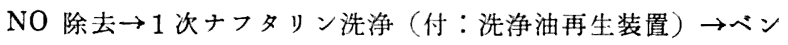
ゾール洗浄 (付：洗浄油再生装置) $\rightarrow$ 湿式脱硫 (付：硫酸製造装 置) $\rightarrow$ 乾式脱硫 $\rightarrow 2$ 次ナフタリン洗浄 (付：洗浄油再生装置) $\rightarrow$ 深泠脱水

このような高圧ガス精製法は今後大ガス工場では甚だ望ましい ものである。また回収したベンジールの精製に水添（コークス犵 ガスを水素源とする）を利用することも興味あることである。

\section{IV. ガスの貯 蔵}

ガス工業にとってガスの貯藏は重要な問題であって，ガスの需 要が增すにしたがってその適当な貯藏法にはいずれも頭を悩まし ている。現在わが国には有水槽有柱ガスダメが最も広く用いられ 
ているが，特殊なものとして無水槽 M.A.N. 式ガスダメと球型 高圧がスダメがある。そしてその工法はすべてのものが鋲止めか らほとんど皆溶接に変ってしまった。

高压ガス精製の場合には必然的に高圧ガスダメが要求される が，単に資材の節約から小工場で球型高圧ガスダメを採用するこ とは他に特殊な理由がないかぎりすすめられない。

有水槽ガスダメは寒冷地では水槽や水封の水の涷結を防ぐため 防寒, 加熱の特殊装置を必要とする。このような場所では Wiggins 式のよ5に水を用いない乾封式のガスダメが興味がある。 この式のタメは石油工業ではすでにわが国でも用いられている が，ガスダメとしては末だ採用されたことがない。

米国やヨーロッパでは天然ガスや製造ガスの地下貯藏がすでに 実用期に入っているが，わが国では未だそのための地質調查さえ されていない。わが国では不可能事かも知れないが，一応研究す る価値のある問題であると思う。

なおガスダメは一度つくれば数十年間使用するものであるか ら，その材質と防食塗料には十分注意する必要がある。ことに塗 料についてはいっそうの研究が望ましい。

\section{V.ガスの供給}

いくら良質のガスができてもそれが一定の適当な圧力で常時需 用家へ届かなければ役に立たない。ここにガス配給導管の重要性 がある。現在どこででも昔布設した導管が需要に対して細すぎる 㥗みを持っものが多い。しかし，これを新たに大口径の管に入れ 替えることは経済的，技術的にむずかしいことが多く，ことに交 通量のきわめて大きい赤装道路等においてはほとんど不可能に 近い。かかる場合二つの方法が考えられる。一はガスの熱是の上 昇であり，他は圧力の上昇である。前者も真剣に考えられている が，技術的，経済的に影響するところが多く，多くは後者の方法 による。しかし現在のままではガスメーターやガス器具の関係上 無暗な圧力上暑はゆるされないが，もしメーターの前にサービス ガバナーを取付けて各需用家ごとに圧力を調整するようにすれば 甚だ都合がよい。しかしわが国では未だこの方法は実施されてお らず，今後この方面の研究が望まれる。

一般に今後のガス笀管については新らしい材質（たとえばプラ スチックスのごとき)，新らしい接手，新らしい分岐管取出し法 等につき研究が望末れる。またその腐食防止のため塗料, 被覆,

電気防食等の技術の向上も望ましい。

ガスの供給の問題の一として，ガスの遠距離輸送のことがあ る。わが国のガス事業発達の歷史からみて, 各都市にそれぞれ独
立のガス事業が扣こり，それが都市の発展とともに桩張されて来 たにすぎないという事実に基いて，わが国ではガスの遠距離輸送 は大して発達せず, 僅かに京浜, 京阪, 阪神等の大都市間の導管 連絡が完成されているにすぎない。しかしガス緗とまではゆかな くともせめて東海道，山陽の鉄道幹線に沿ってガス輸送管ができ ていさえすれば，わが国のガス工業の様相はかなり変ったものに なっているであるう。ガスの集中生産と遠距離輸送は好むと好ま ざるにかかわらず，世界的の傾向であることからみても，わが国 でも急速ではないとしてもその方向に向うことは疑いない。

ガスの供給に関連してメーターの問題がある。これは軲次改良 されたとはいえ，100 年以上も同じプリンシプルにより，自然物 である羊皮を使っている。これを電気メーターないし量水計にく らべると不恰好であることを免れない。ただ戦後米国で人工の琵 膜が使われ出して好成績であることは一つの進步であるが，なお 進んでオールメタルのガスメーターの出現が待たれる次第である。

\section{VI. ガスの応用}

ガスは器具で使用されて初めてその洒值を示すものである。す なわちガスの性質と器具との関係は一般の人が考えている以上に 大切なことである。

戦前はわが国のガスはもっぱら石炭ガス基のものであって，そ の成分も熱量もともに場所により，また時代によって大した変化 がなく，器具もまたそれに適するよ5に製作されていた。それが 戦後は石炭ガス以外に天然ガス, 油ガス, LPG 等新らしい種類 のガスが多く用いられるようになり, ·初めはガス製造のエンジニ ーアも器具のエンジニーアも十分知識がなく, 種々不都合を来し たこともあったようであるが，やっとガスの燃焼性の研究の重要 性に気付いてぼつぼつその方面の研究と器具の構造の改良に関心 が出て来たことは慶ぶべきことである。しかし外国，ことにフラ ンス，英国等にくらべるとこの方面の研究は未だ非常におくれて いるといわなければならぬ。

都市ガスは単に家庭用または商工業用の然料としてだけでな く, 冷蔵, 冷房, 增炭等にも用いられるものであって, ガスの新 用途開拓はガスエンジニーアに課せられた使命の一であることを 忘れてはならない。

終汇臨み本文中に述へた意見，批評はすべて筆者個人のもので あり，引用の統計は日本瓦斯協会編“ガス統計”, UN Economic Mission for Europe 編"The Trend of European Gas Economy”拈よび W.P.C. “Stastical Year Book, No. 7”によっ たことを付記する。

(24. 2. 1957) 